\title{
Phaeosphaeria deschampsii J. Putzke \& A.B.Pereira (Ascomycota, Fungi) causing whitening in Deschampsia antarctica Desv. (Poaceae) in the South Shetland Islands
}

\author{
Antonio Batista Pereira ${ }^{1 *}$, Jorge Renato Pinheiro Velloso ${ }^{1}$, Jair Putzke ${ }^{1}$ \\ 1 Universidade Federal do Pampa, São Gabriel, Rio Grande do Sul, Brazil•ABP: antoniopereira@unipampa.edu.br $@$ https://orcid.org/0000-0003- \\ 0368-4594 •JRPV: jorgerenatovelloso@gmail.com (1) https://orcid.org/0000-0001-7787-0336•JP: jairputzke@unipampa.edu.br (1) https://orcid. \\ org/0000-0002-9018-9024 \\ * Corresponding author
}

\begin{abstract}
Phaeosphaeria deschampsii was described from dead leaves of Deschampsia antarctica (Antarctic Grass). We surveyed other islands of the South Shetland archipelago, Antarctica, and also found Arctic Grass whitening, the disease associated with this fungus, indicating that is disease is widespread.
\end{abstract}

Keywords

Diseases, distribution, phytopathology, symptoms.

Academic editor: Jadson Bezerra | Received 24 September 2021 | Accepted 5 December 2021 | Published 23 December 2021

Citation: Pereira AB, Velloso JRP, Putzke J (2021) Phaeosphaeria deschampsii J. Putzke \& A.B.Pereira (Ascomycota, Fungi) causing whitening in Deschampsia antarctica Desv. (Poaceae) in the South Shetland Islands. Check List 17 (6): 1751-1754. https://doi.org/10.15560/17.6.1751

\section{Introduction}

Phaeosphaeria I. Miyake is a genus of fungi in which all described species are parasitic on Poaceae and some other grass-like monocotyledons. Some species are very specialized while others have a large host spectrum (Stchigel et al. 2004). In the revision of the family Phaeosphoracea by Phookamsak et al. (2014), Phaeospheria sensu stricto has five clearly known species delimited by molecular data.

Phaeosphaeria deschampsii J. Putzke \& A.B. Pereira is a cause of a disease in Deschampsia antarctica Desv. (Antarctic Grass; family Poaceae), which until now is the only known host of this species of fungi. The symptoms are leaf lesions resulting from the eruption of foliar tissue forming numerous ascomes, which result in the death and complete depigmentation of leaves and stems (Putzke and Pereira 2016). Deschampsia antarctica occurs at the extreme southern parts of Argentina and Chile, as well as on the Antarctic Peninsula. It is also frequently found on the sub-Antarctic islands, such as the South Georgian and South Orkney islands. In Antarctica, it is found on most of the South Shetland Islands, and its southernmost occurrence is on the Antarctic Peninsula (Parnikoza et al. 2011). Deschampsia antarctica was reported from as far north in Chile as $51^{\circ} \mathrm{S}$, where it was frequent in the fields on the outskirts of the city of Punta Arena (Moore 1983).

Putzke and Pereira (2016) described P. deschampsii and the symptoms and signs of the disease from specimens collected on Half Moon Island, South Shetlands, Antarctica, during the southern summer 2013/2014. They 
also surveyed other islands in the same archipelago for the presence of disease (Antarctic Grass whitening) caused by $P$. deschampsii.

Here, we present new records of $P$. dechampsii based on surveys we carried out in other islands of the South Shetland archipelago.

\section{Methods}

King George, Snow, Elephant, Nelson, Penguin, Robert, Greenwish, Deception, and Livingston islands of the South Shetland archipelago were surveyed for the occurrence of the Antarctic Grass whitening (Fig. 1). Dead leaves (Fig. 2) were inspected to find the reproductive structures of the fungi (Fig. 3) to confirm its association. In the laboratories of the Universidade Federal do Pampa, transversal sections were made on the isolated perithecia to examine the cell organization in the ascoma wall and neck, asci, and ascospores using a Carl Zeiss microscope. The fungi were identified using anatomical and morphological characteristics according to the literature (Sivanesan, 1984; Schoemaker and Babcock 1988; Möller and Dreyfuss 1996; Stchigel et al. 2004). The collected samples were dried and are deposited in the HCB and HBEI herbaria.

\section{Results}

Our field expeditions have found symptoms on Deschampsia antarctica in the Keller Peninsula and Hennequin Point (King George Island), Stinker Point (Elephant Island), Byers Peninsula (Livingston Island), and Snow Island.

Material examined. ANTARCTIC - Half Moon Island - Xenia Hill; 62 $34^{\prime} 50^{\prime \prime} \mathrm{S}, 059^{\circ} 56^{\prime} 04^{\prime \prime} \mathrm{W} ; 89 \mathrm{~m}$ alt.; 10.II.2014; J. Putzke leg.; HCB 18077 - Elephant Island - Stinker Point; $61^{\circ} 13^{\prime} 18^{\prime \prime} \mathrm{S}, 055^{\circ} 21^{\prime} 54^{\prime \prime} \mathrm{W} ; 25 \mathrm{~m}$ alt.; 1.III.2012; J. Putzke leg.; HCB 18078 - King George Island • Keller Peninsula; $62^{\circ} 04^{\prime} 58^{\prime \prime} \mathrm{S}, 058^{\circ} 23^{\prime} 30^{\prime \prime} \mathrm{W} ; 5 \mathrm{~m}$ alt.; 10.II.2014; A. B. Pereira leg.; HBEI 1615.

Identification. The fungus which caused the disease is characterized by the presence of ascoma in the form of numerous perithecia, mainly on leaves, $250 \times 500 \mu \mathrm{m}$ in diameter, and with an oblique neck 40-50 × 70-80 $\mu \mathrm{m}$. The wall of each perithecium is composed of brown polygonal cells, 5-7 × 5-7 $\mu \mathrm{m}$. The ostiole is $25-45 \mu \mathrm{m}$ in diameter, and the asci are cylindrical, 100-120 × 10 $14 \mu \mathrm{m}, 8$-spored, biseriate with fusiform, straight, or slightly curved ascospores. The ascospores are 25-30 $\times 6-7 \mu \mathrm{m}, 8$-septate, hyaline when young, turning yellowish-brown when mature, and with the first septum

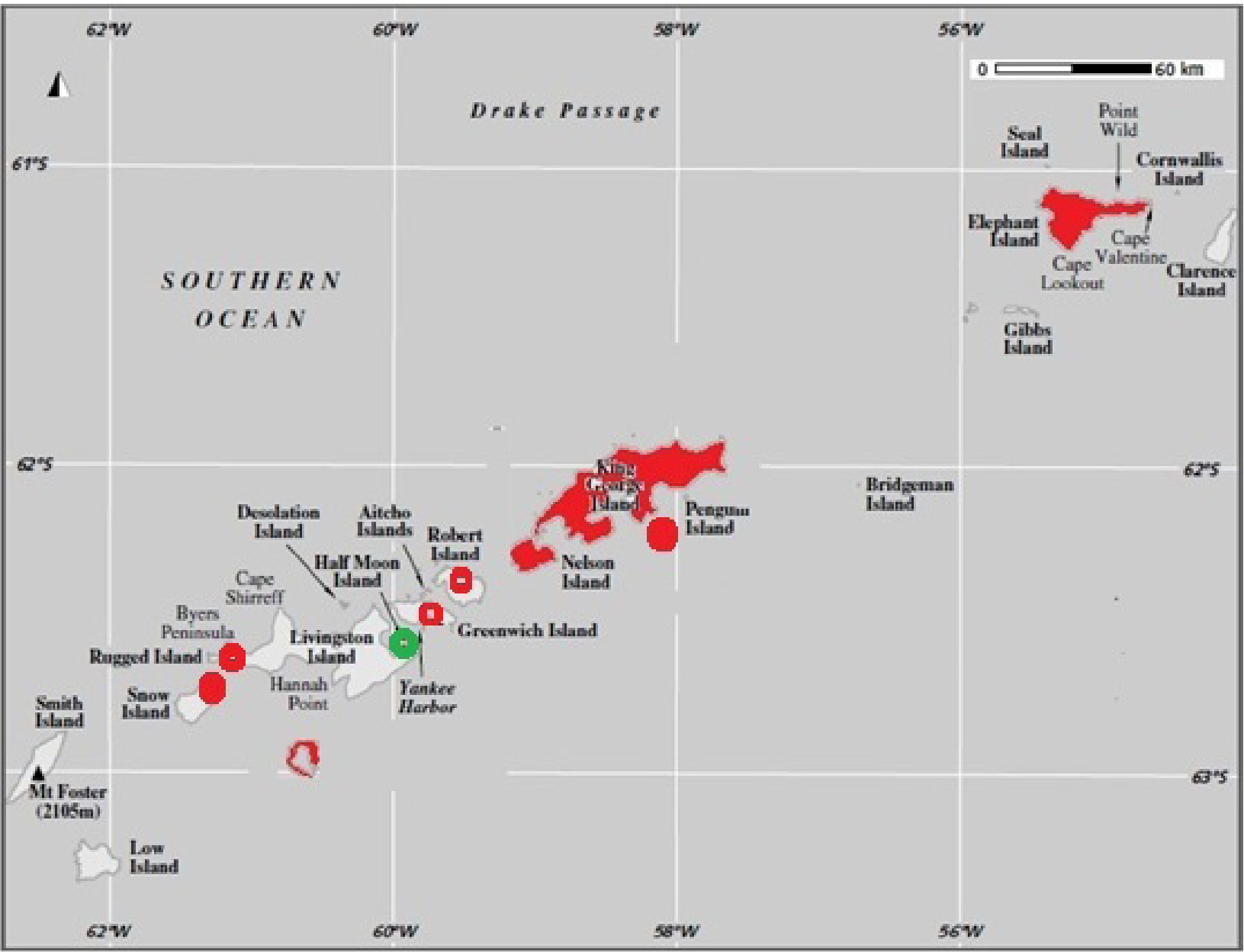

Figure 1. South Shetland Islands studied for the occurrence of the Antarctic Grass disease, indicating original place of collection (green circle) and new occurrences (red). 

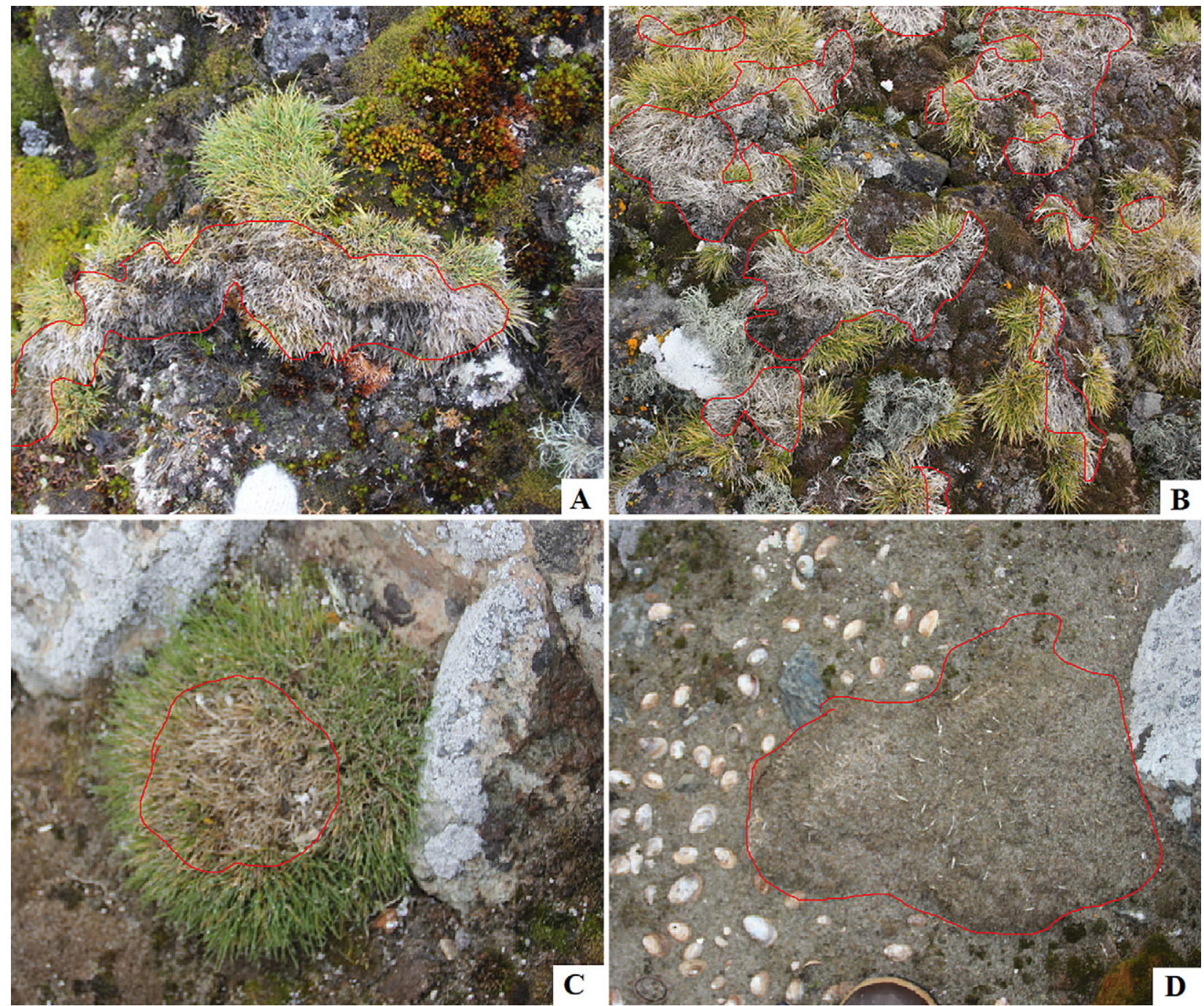

Figure 2. The Antarctic Grass whitening (a red line surrounds the symptom). A. Half Moon Island. B. King George Island. C, D. Snow Island (with $D$. antarctica completely dead in $\mathbf{D}$ ).

submedial, constricted, eguttulate, smooth, and without a mucous sheath. Phaeosphaeria deschampsii is distinguished morphologically from other species of the genus by the oblique neck of the perithecia, which are erumpent on grass leaf tissues and have ascospores with eight septa (Fig. 3).

\section{Discussion}

Few studies have been published so far on the pathogenic potential of the microbiota, especially fungi in Antarctica. The first studies of fungi associated with Antarctic plants, such as Deschampsia antarctica, already mention, among others, the genus Phaeosphaeria, but without correlating its presence as a potential pathogen (Pugh and Allosopp 1982; Fletcher et al. 1985; Gamundi and Spinedi 1988; Onofri and Tosi 1989; Del Frante and Caretta 1990; Baublis et al. 1991; Möller and Dreyfuss 1996).

Phaeosphaerica deschampsii was recently discovered by Putzke and Pereira (2016) as a new parasite of D. antarctica on Halfmoon Island $\left(62^{\circ} 36^{\prime} \mathrm{S}, 059^{\circ} 53^{\prime} \mathrm{W}\right)$, which is between Livingston and Greenwich islands in the South Shetland Archipelago. Here, we report the fungus again associated with $D$. antarctica but on other islands of the archipelago, which shows the great spread of the disease in Antarctica. The microscopic examination shows that the same structures in the original description were found in our new samples.

Phaeosphaeria mounceae Shoemaker \& C.E.Babc. is the most similar species of Phaeosphaeria to P. deschampsii, but it is well-differentiated by the erumpent, obliquely necked perithecia and 8-septate ascospores (Shoemaker and Babcock 1988). Phaeosphaeria microscopica (Karsten) O. Erikss. was reported by (Stchigel et al. 2004) from Antarctica; it is a widespread species, which differs in having 3-septate ascospores (Putzke and Pereira 2016).

The Arctic Grass whitening disease seems to be more common and has spread within a range of 400 $\mathrm{km}$ from the northernmost point of Elephant Island to the southernmost point of Snow Island, and possibly all grass populations in the South Shetland Islands are infected. Our evaluation performed five years after the discovery of the species by Putzke and Pereira (2016) on infected grasses on Elephant and King George islands 


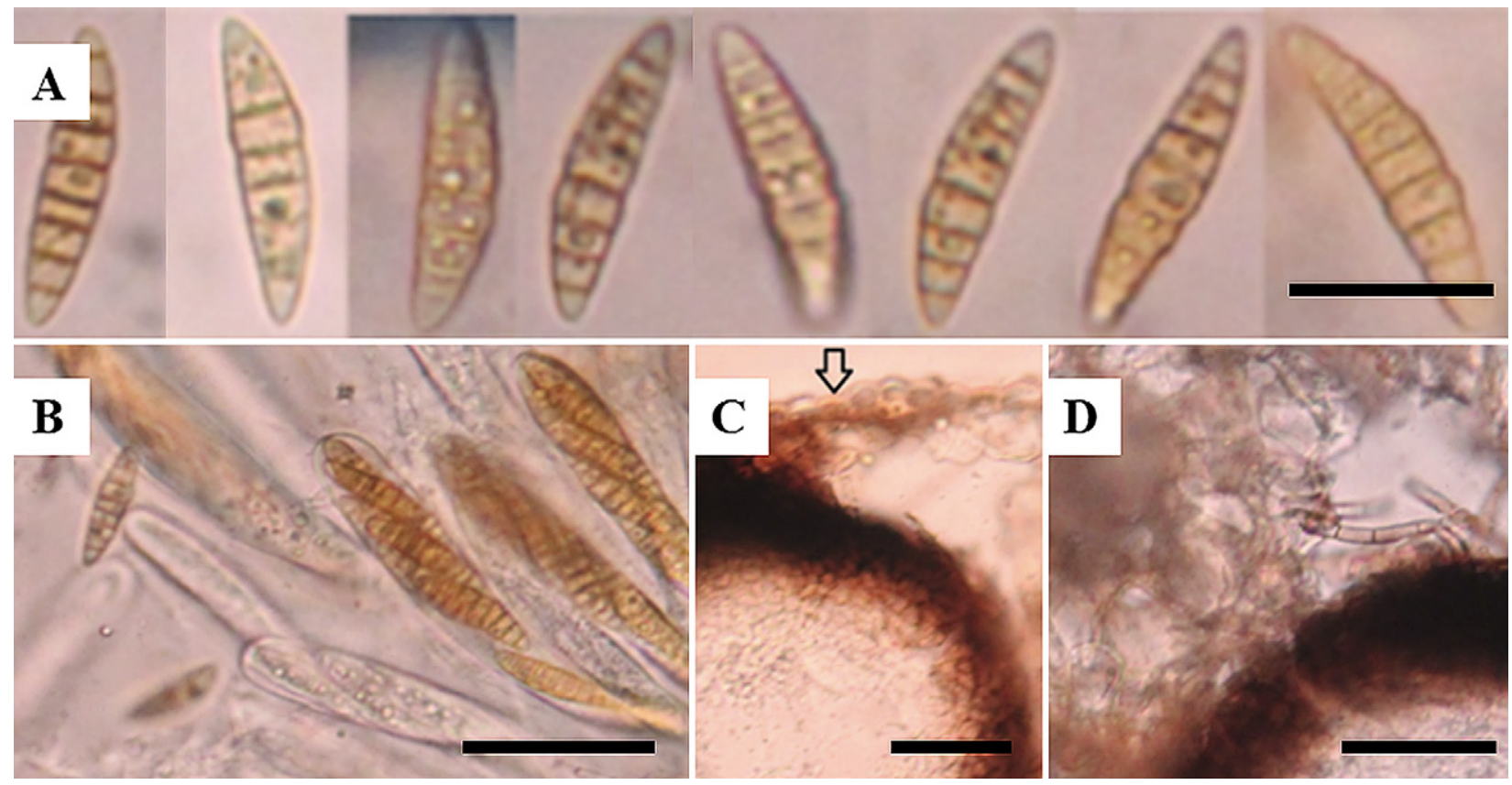

Figure 3. A. Ascospores. B. Some mature asci together with some young ones. C. Perithecial wall and epidermal cells of the host (arrow). D. Loosely disposed hyphae in the perithecia outer wall. Scale bars: $A=20 \mu \mathrm{m} ; B-D=50 \mu \mathrm{m}$.

(Hennequin Point) found that the symptoms had become more intense in all specimens with increased and more severe damage to leaves. More fungi were also found on diseased leaves and stem, suggesting that that other fungi could also be causing the disease, but more research is needed to understand the fungi/plant relationship.

\section{Acknowledgements}

We thank the Federal University of Pampa, the reviewers, for their excellent contributions to the work, the editor, and the CNPq (proc. 470349/2013-1).

\section{Authors' Contributions}

Conceptualization: ABP, JRPV, JP. Data curation: JRPV, ABP, JP. Formal analysis: JRPV, ABP, JP. Funding acquisition: JP, ABP, JRPV. Investigation: JRPV, ABP, JP. Methodology: ABP, JP, JRPV. Project administration: JRPV, ABP, JP. Resources: JP, ABP, JRPV. Software: JP, JRPV, ABP. Supervision: JP, ABP, JRPV. Validation: JP, JRPV, ABP. Visualization: JP, ABP, JRPV. Writing original draft: ABP, JRPV, JP. Writing - review and editing: JRPV, JP, ABP.

\section{References}

Baublis JA, Wharton RA, Volz PA (1991) Diversity of microfungi in an Antarctic dry valley. Journal of Basic Microbiology 31: 3-12. https://doi.org/10.1002/jobm.3620310102

Del Frante GD, Caretta G (1990) Fungi isolated from Antarctic ma- terial. Polar Biology 11: 1-7. https://doi.org/10.1007/BF00236515 Fletcher LD, Kerry EJ, Weste GM (1985) Microfungi of MacRobertson and Enderby Lands, Antarctica. Polar Biology 4: 81-88.

Gamundi IJ, Spinedi HA (1988) New species and interesting collections from Danco Coast, Antarctic Peninsula. Mycotaxon 33: 467-498.

Möller C, Dreyfuss MM (1996) Microfungi from Antarctic lichens, mosses and vascular plants. Mycologia 88: 922-933.

Moore DM (1983) Flora of Tierra del Fuego. Anthony Nelson, Shrewsbury, UK, ix +396 pp.

Onofri S, Tosi S (1989) II contributo della micologia alla IV spedizione italiana in Antartide. Micologia e Vegetazione Mediterranea 4: 57-62.

Parnikoza I, Kozeretska I, Kunakh V (2011) Vascular plants of the maritime Antarctic: origin and adaptation. American Journal of Plant Sciences 2: 381-395. http://doi.org/10.4236/ajps.2011.23044

Phookamsak R, Jian-Kui Liu J, McKenzie, EHC, Manamgoda DS, Hiran Ariyawansa H, Thambugala KM, Dai D, Camporesi E, Chukeatirote E, Wijayawardene NN, Bahkali AH, Mortimer PE, Xu J, Hyd KD (2014) Revision of Phaeosphaeriaceae. Fungal Diversity 68: 159-238. https://doi.org/10.1007/s13225-014-0308-3

Pugh GJF, Allosopp D (1982) Microfungi on Signy Island, South Orkney Islands. British Antarctic Survey Bulletin 57: 55-67.

Putzke J, Pereira AB (2016) Phaeosphaeria deschampsii (Ascomycota): A new parasite species of Deschampsia antarctica (Poaceae) described to Antarctica. Anais da Academia Brasileira de Ciências 88 (Supplement 3): 1967-1969. http://doi.org/10.1590/00013765201620150779

Sivanesan A (1984) The bitunicate Ascomycetes and their anamorphs. J. Cramer, Vaduz, Germany, 701 pp.

Shoemaker RA, Babcock CE (1988) Phaeosphaeria. Canadian Journal of Botany 67: 1500-1599. https://doi.org/10.1139/b89-199

Stchigel AM, Calduch M, Cormak M, Garro J (2004) Phaeosphaeria microscopica (Karsten) O. Erikss.: first report on Deschampsia antarctica Desv. Boletín Micológico 19: 111-115. 